$\epsilon$ NORMAE ( $\alpha=16^{\text {h }} 19 \mathrm{~m} 8 ; \delta=-47^{\circ} 20^{\prime}$; Mag. 4.7; Class B4)

\begin{tabular}{|c|c|c|c|c|}
\hline \multirow{3}{*}{$\begin{array}{c}\text { Gr. M. T. } \\
\text { 1908 July } 23.565\end{array}$} & $\begin{array}{l}\text { Vel. } \\
\mathrm{km} \text {. }\end{array}$ & Observer & \multicolumn{2}{|l|}{ Measured by } \\
\hline & $\begin{array}{l}+\quad 2 \\
+\quad 7\end{array}$ & Paddock & $\begin{array}{l}\text { Sanford } \\
\text { Olivier }\end{array}$ & \\
\hline & +4 & & Miss Hobe & 7 \\
\hline 1911 May 16.780 & -14 & Paddock & Mrs. Moore & \\
\hline & -10 & & Miss Hobe & 8 \\
\hline May 29.728 & -13 & Moore & Mrs. Moore & 2 \\
\hline & -11 & & Miss Hobe & 5 \\
\hline June 12.710 & $\begin{array}{l}-144\} \\
+80\}\end{array}$ & & Miss Hobe & $\begin{array}{l}8 \text { double lines } \\
10\end{array}$ \\
\hline 1912 May 25.754 & $\begin{array}{l}-20 \\
+\quad 4\end{array}$ & Sanford & $\begin{array}{l}\text { Mrs. Moore } \\
\text { Miss Hobe }\end{array}$ & $3, \mathrm{H} \gamma$ double? \\
\hline 1915 June 6.736 & $\begin{array}{l}+19 \\
+14\end{array}$ & Scott & $\begin{array}{l}\text { Wilson } \\
\text { Scott }\end{array}$ & $\begin{array}{l}4,1 \text { prism } \\
3\end{array}$ \\
\hline Aug. 17.566 & $\begin{array}{l}+85\} \\
-1195\end{array}$ & & Scott & $\begin{array}{l}\text { 8, double, } \\
1 \text { prism }\end{array}$ \\
\hline & $\begin{array}{l}+84\} \\
-87\}\end{array}$ & & Wilson & 2 , double \\
\hline
\end{tabular}

The spectrum contains broad lines of hydrogen and helium. On the spectrograms of June 12, 1911, and Angust 17, 1915, both spectra appear; while on those of May 29, 1911, May 25, 1912, and June 6, 1915, the lines are hazy, with the appearance of being double. The separation, however, is not sufficient to permit of approximate measurement.

$\kappa$ SCORPII ( $\alpha=17^{\mathrm{h}} 35^{\mathrm{m}} 6 ; \delta=-38^{\circ} 59^{\prime} ;$ Mag. 2.5 ; Class B2)

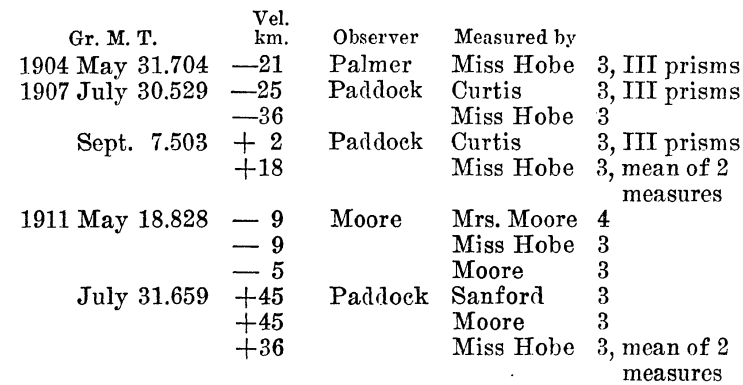

\begin{tabular}{|c|c|c|c|c|}
\hline $\begin{array}{c}\text { Gr. M. T. } \\
1912 \text { June } 10.769\end{array}$ & $\begin{array}{r}\text { Vel. } \\
\text { km. } \\
-21 \\
-17\end{array}$ & $\begin{array}{l}\text { Observer } \\
\text { Moore }\end{array}$ & $\begin{array}{l}\text { Measured by } \\
\text { Moore } \\
\text { Miss Hobe }\end{array}$ & $\begin{array}{l}3 \\
3\end{array}$ \\
\hline 1915 June 20.767 & $\begin{array}{l}-11 \\
-35 \\
-27\end{array}$ & Wilson & $\begin{array}{l}\text { Wilson } \\
\text { Scott }\end{array}$ & $\begin{array}{l}10,1 \text { prism } \\
12\end{array}$ \\
\hline June 22.788 & $\begin{array}{l}-24 \\
-12\end{array}$ & Scott & $\begin{array}{l}\text { Wilson } \\
\text { Scott }\end{array}$ & ${ }_{9}^{10,1}$ prism \\
\hline
\end{tabular}

The spectrum contains rather broad lines of hydrogen and helium. A comparison of the spectrograms of May 18 and July 31, 1911, on the Hartmann engine checks the difference in velocity indicated above for these two observations. The lines on the three plates obtained with three-prism dispersion are very broad, and the results from these spectrograms are therefore entitled to small weight.

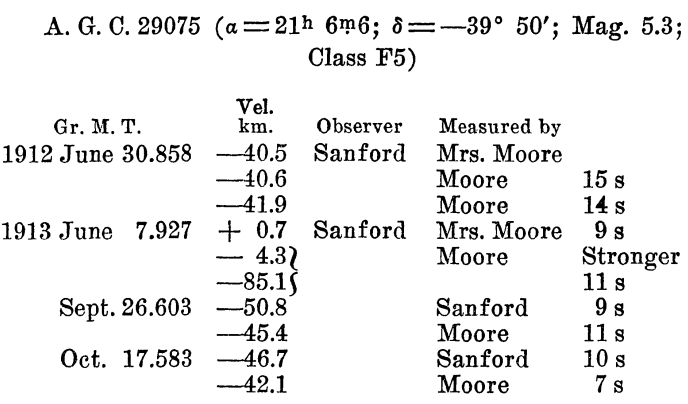

The spectra of both components are visible on the plate of June 7, 1913. That of the stronger component only was measured by one of the observers. The last three plates are underexposed, and the last one is so faint that the results from it are entitled to smaller weight than those from the other measures.

J. H. MOORE.

Mount HamiLton, June 1, 1916.

\title{
FOUR STARS WHOSE RADIAL VELOCITIES ARE VARIABLE
}

Of the stars whose radial velocities are being determined by the D. O. Mills Expedition to the Southern Hemisphere a number observed during the past year give indications of having variable velocities. For several of these the observed variations are such as to make a confirmation by further observations desirable. The range observed for four stars is sufficient, however, to remove all doubt as to the reality of this variation, and for these the necessary data are given below. Except where noted the spectrograms were obtained with a one-prism spectrograph. The number of lines from which the radial velocity was determined follows the measurer's name.
A. G. C. 8815 ( $a=6^{\text {h }} 57 \mathrm{~m} 0 ; \delta=-25^{\circ} 4^{\prime} ;$ Mag. 5.8; Class B3)

$\begin{array}{crllr} & \text { Vel. } & & \\ \text { Gr. M. T. } & \text { km. } & \text { Observer } & \text { Measured by } \\ \text { 1915 Mar. } 14.559 & +12 & \text { Wilson } & \text { Sanford } & 10 \\ & +6 & & \text { Seott } & 8 \\ & +9 & & \text { Wilson } & 8 \\ \text { Oct. } 19.861 & -11 & \text { Seott } & \text { Wilson } & 7 \text {, II prisms } \\ & -13 & & \text { Seott } & 5 \\ \text { Oct. } 25.853 & -11 & \text { Wilson } & \text { Wilson } & 9 \\ & -7 & & \text { Scott } & 6 \\ \text { Nov. } 10.783 & +53 & \text { Wilson } & \text { Wilson } & 11 \\ & +58 & & \text { Scott } & 12\end{array}$

The spectrum contains several good lines for either one- or two-prism dispersion, the principal ones being of hydrogen, helium, calcium and magnesium. 


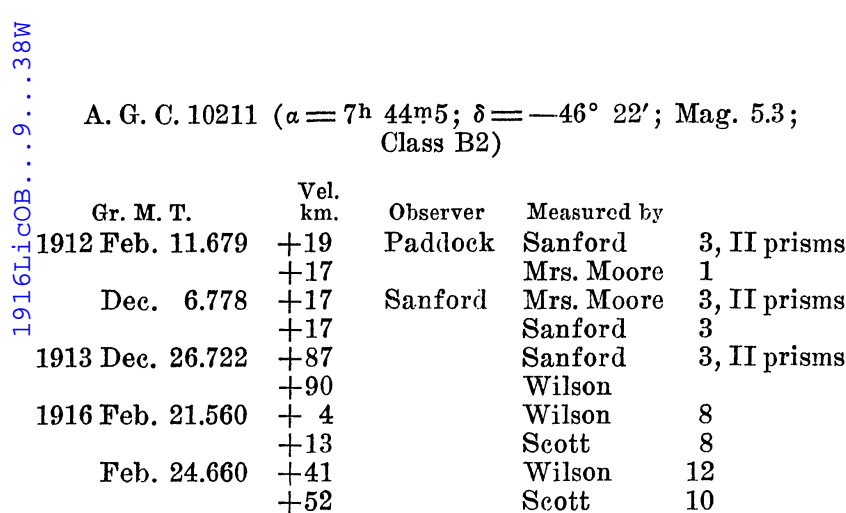

The lines of hydrogen and helium upon which the measures depend are rather broad for the dispersion of two prisms. The character of the lines appears to change.

\begin{tabular}{|c|c|c|c|c|}
\hline K VELORUM $(a=$ & 9 h $14 \mathrm{~m} 7$ & $; \delta=-$ & $38^{\prime} ;$ Mag & 3 ; Class A \\
\hline Gr. M. T. & $\begin{array}{l}\text { Vel. } \\
\text { km. }\end{array}$ & Observer & Measured by & \\
\hline 1913 Feb. 11.744 & +86 & Sanford & Mrs. Moore & 2, II prisms \\
\hline 1914 Mar. 19.660 & $\begin{array}{l}+89 \\
+105 \pm\end{array}$ & & $\begin{array}{l}\text { Moore } \\
\text { Wilson }\end{array}$ & 1, II prisms \\
\hline & $+110 \pm$ & & Campbell & \\
\hline & $+124 \pm$ & & Scott & \\
\hline Apr. 16.601 & +44 & & Wilson & 2, II prisms \\
\hline & +45 & & Sanford & \\
\hline & +24 & & Scott & 2 , mean of 2 \\
\hline 1916 Feb. 16.760 & +17 & & Wilson & 5 \\
\hline & +20 & & Scott & 4 \\
\hline Feb. 23.596 & +80 & & Wilson & 7 \\
\hline & +98 & & Scott & 6 \\
\hline
\end{tabular}

With two-prism dispersion the lines of hydrogen and magnesium are rather difficult, as the $\mathrm{H}_{\gamma}$ is broad and the 4481 line is faint. On the spectrograms obtained with the one-prism spectrograph the hydrogen lines are fairly sharp, and their measures are entitled to more weight than those of the higher dispersion spectrograms.

$$
\begin{array}{ccccc}
\chi^{2} \text { Hrdrae }\left(\alpha=11^{\mathrm{h}} 1 \mathrm{~m} 1 ; \delta=-26^{\circ}\right. & 45^{\prime} ; \text { Mag. } 5.6 \text {; Class B8) } \\
\multicolumn{5}{c}{\text { Vel. }} \\
\text { Gr. M. T. } & \text { km. } & \text { Observer } & \text { Measured by } \\
\text { 1915 June 24.506 } & -57 & \text { Scott } & \text { Wilson } & 2 \\
& -56 & & \text { Scott } & 2,4 \text {, mean of two } \\
\text { June 25.483 } & +134 & \text { Scott } & \text { Wilson } & 3,5 \text {, mean of two } \\
& +156 & & \text { Scott } & 5,5 \text {, mean of two } \\
\text { July } 6.497 & +95 & \text { Scott } & \text { Wilson } & 2,2 \text {, mean of two } \\
& +68 & & \text { Scott } & 2,4, \text { mean of two }
\end{array}
$$

The spectrum contains broad lines of hydrogen, fair magnesium and very weak helium lines. The helium lines are not in general measurable.

RALPH E. WILSON.

\author{
Observatory of the D. O. Mills Expedition, \\ Santiago, Chile, \\ March, 1916.
}

\section{RS SAGITTARII, ALGOL VARIABLE AND SPECTROSCOPIC BINARY}

RS Sagittarii $\left(18^{\mathrm{h}} 11^{\mathrm{m}} 0,-34^{\circ} 8^{\prime}\right)$, a variable star of the Algol type according to the Second Catalogue of Variable Stars (Annals Harvard College Observatory, 55, 22, 1907), was observed along with a group of other variables in 1909 at Santiago, Chile, for the purpose of finding variable radial velocity. A single prism and 16-inch camera were used, these giving the lowest dispersion then available in the equipment of the D. O. Mills Expedition. Nine plates of RS Sagittarii were obtained. Preliminary measures of the wide lines of the Class A spectrum shown by this star give a range of $160 \mathrm{~km}$., that is, from $+80 \mathrm{~km}$. to $-80 \mathrm{~km}$. This result indicates that the star is a spectroscopic binary, one body eclipsing the other, in view of the nature of the light curve. Definitive measures of velocity will be published later. Further observations and measures of this star in 1915 with one-prism dispersion, by Dr. R. E. Wilson at Santiago, corroborate this variation of velocity, giving a range of $140 \mathrm{~km}$.

\section{G. F. PADDOCK.}

June, 1916. 